\title{
PSYCHE.
}

\section{A PROBABLE NEW TYPE OF HYPERME'TAMORPHOSIS.}

\author{
BY JAMES G. NEEDHAM, LAKE FOREST, ILL.
}

While collecting stone-flies in Fall Creek at Ithaca, N. Y., in July, I90I, I found attached to some of the smaller stones in the edges of the current numerous larval and pupal cases of microcaddis-flies. I was not at first entirely certain that they were caddis-fly cases : but I took a few of them into the laboratory and examined their contents. One contained a larva of the form shown in fig. I, easily referable to the family Hydroptilidae of Trichoptera; one contained a transforming larva (prepupa: subnympha) of the form shown in fig. 2 - a form so unusual in this family as to awaken immediate interest; and the remainder contained pupae. The cases were $3 \mathrm{~mm}$. long, of the form shown in fig. 5, elongate oval, with a process at each end for attachment to the stone, thin, flat, of a yellowish brown color, and so translucent that the stage of development of the contained animal could be easily recognized under the microscope before opening them. Such cases have not hitherto been known for caddis-fly larvae: they probably represent a genus of Hydroptilidae for which the immature stages have not been described - perhaps Phryxicoma, to which genus the two lone American specimens of which our literature treats, have been referred.

I was then so fully occupied with the study of other aquatic insects that I could give but little time or attention to these: but I wished to see more of that singular prepupa, and I managed to spend an hour on the $I x$ th of July collecting especially for it. I found the cases everywhere on the vertical surfaces of stones washed by a swift current, and had no difficulty in gathering for preservation several dozen of them. Recently I have studied this material. It contained three larvae of the sort shown in fig. I, three prepupae of the form shown in fig. 2 and a very large number of pupae with the general appearance sketchily shown in fig. 5 . The small number found in the earlier stages, and the considerable number of empty cases found, showed the season of transformation was well advanced. Two of the larvae were still active when collected: I saw them moving freely within their cases, though the apertures at the ends seemed to be already closed. Most Hydroptilid larvae carry their cases with the thin edge upward, and in trans- 
formation, when the case is attached flatwise, lie on their side; but these larvae lay on the venter, and the depressed abdomen with its short recurved hairs seemed to indicate that as the normal position. Prepupa and pupa lie likewise with the ventral surface to the stone, the former with the head and thorax and terminal abdominal segments twisted to the left side. At this stage the most remarkable feature of the animal is the presence of five pairs of appendages jointed upon the sides of abdominal segments $3-7$. Such appendages are wholly unknown in this order (although quite characteristic of several aquatic genera of the Neuroptera); and if, as I suppose, these larvae, prepupae, and pupae form a single series representing one species, their transitory appearance at the end of larval life is a deviation from the normal course of metamorphosis wholly without a parallel.

The nature of these appendages is shown in detail in figures 4 and 5 . Figure 4 is an external view and shows how completely the appendage is articulated to the side of the abdominal segment. Figure 5 is a frontal section of the same and shows its internal structure. There is, as everywhere, an outer layer of hypodermis (shown as a line of dots) to which the old and loosened cuticle, which has not participated in the articulation, does not conform; there are two tracheae passing out from the body cavity into the appendage and repeatedly branching there, and penetrating the mass of fat tissue which fills the entire cavity, and which is entirely similar to the fat filling the lateral extension of the abdominal segment which supports the appendage: there are no other tissues entering into its composition.

Two fairly distinct types of hypermetamorphosis have been distinguished hitherto: one of these occurs among the Hymenoptera and is apparently restricted to egg parasites (Platygaster, Polynema, Teleas, etc.): among these the hatching of the egg occurs apparently very early, and the earliest free stages are regarded as embryonic rather than larval; obviously, our caddis-fly has nothing to do with this type.

The other type occurs among the Neuroptera (Mantispa) and Coleoptera (Epicauta, Meloe, Sitaris, etc.). Among these the larva hatches six-legged and active (Campodeiform) and during its larval life becomes footless, sluggish and distended with accumulated fat (Eruciform). These forms are held to furnish the best of ontogenetic evidence as to the course of development of complete metamorphosis among insects. The striking change of form, which here constitutes hypermetamorphosis, occurs during the period of larval growth, and is therefore unlike that which we are describing.

There is also in those insects whose transformation is most complete and rapid, after the cessation of feeding on the part of the larva, a period of making over into the pupal form: this prepupal stage is due to the swelling and shortening of the larva under its loosened cuti- 
cle. While the most striking forms of prepupae hitherto described (Agrioytpus, etc.) have been pointed out as cases of hypermetamorphosis, it is to be noted that they are all forms strictly interme-
Our caddis-fly, however, is apparently worthy to be ranked as an illustration of a third type. Besides the three normal developmental stages, it takes on in the prepupal period characters which do not

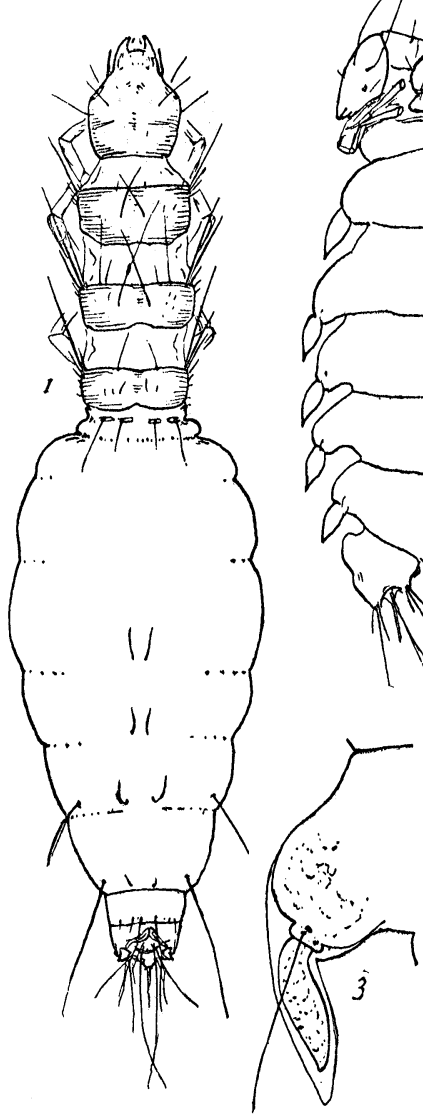

diate between the larva and the pupa, and all exceedingly transitory, gradually but quickly assumed and quickly lost again, and not truly hypermetamorphic, in the same sense as are the two types mentioned above.

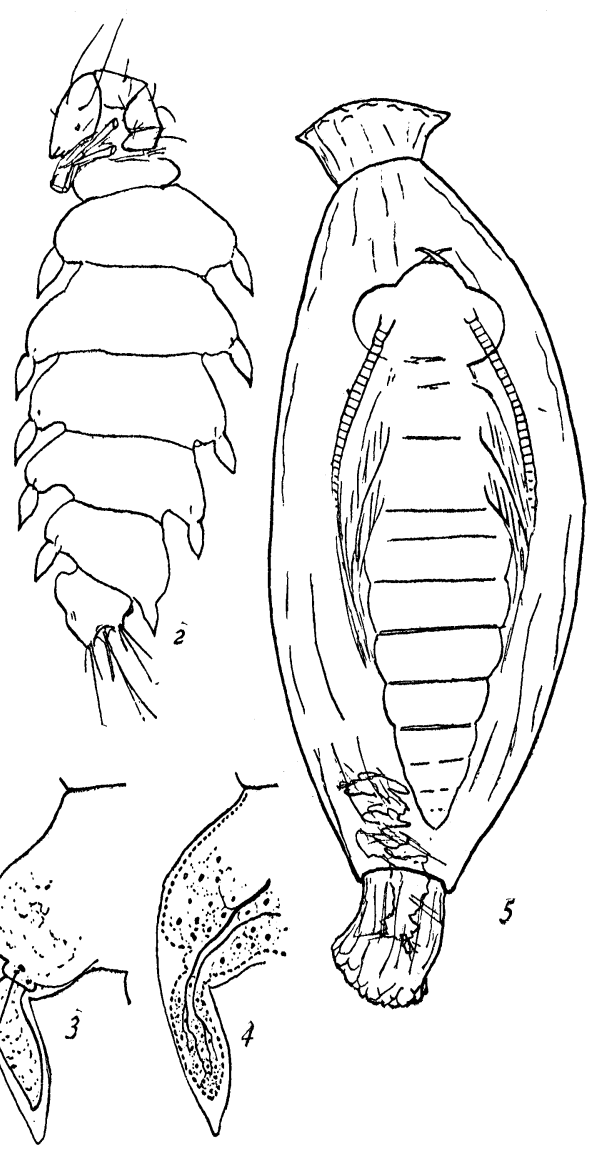

belong to either larva or pupa, and are not intermediate between these stages.

The possibility that my specimens did not all belong to the same species, and that these peculiar appendages of the prepupa may have belonged to the larva 
of the same species, is not to be entirely overlooked, even though it be highly improbable. The discovery of such appendages on a Trichopterous larva would, indeed, be sufficiently surprising. The gills of Trichopterous larvae are simple or tufted filaments; and the larvae of the Hydroptilidae, so far as known, do not possess even these. Stout processes, articulated at the sides of the abdomen and arranged segmentally are entirely unknown in this order, but occur in certain Coleopterous and Neuropterous larvae. Most like the appendages of our prepupa are the lateral filaments of the larvae of Sialidae, especially, of Sialis: here the several jointed lateral processes are articulated to the sides of the abdomen. In Sisyra and Climacia (family Hemerobiidae of Neuroptera) are similar, jointed filaments directed toward the midventral line beneath the abdomen.

I am inclined to believe that these appendages are inherited from some remote, primitive Neuropterous type. I regard them as belonging in the same category as the large, transitory mandibles of the pupa.

\section{RECORDS OF THE HABITS OF NEW MEXICAN COLEOP'TERA.}

BY T. D. A. COCKERELL, EAST LAS VEGAS, N. MEX.

Unless the contrary is specified, the authority for the identification is in every case Mr. H. C. Fall, to whom I am under the greatest obligations. When the collector's name is not given, the material was collected by the present writer. Townsend $=$ C. H. T. Townsend. Wooton $=$ E. O. Wooton.

Cicindela sperata Lec. Rincon, July 5 ; numerous in the bed of the Rio Grande, copulating.

Hippodamia sinuata Muls. Mescalero, on Chrysothamnus graveolens glabratus, Oct. I.

Coccinella oculata Fab. Mescalero, on Chrysothamnus graveolens glabratus, Oct. 2 .
Psyllobora 20-maculata Say. Rio Ruidoso, about $6500 \mathrm{ft}$., on Rhus glabra, July 24. (Townsend).

Chrysobothris carinipennis Lec. Rio Ruidoso, about $6_{500} \mathrm{ft}$., on cut pine branches, Aug. 4. (Townsend).

Chrysobothris debilis Lec. (det. Wickham). In coitu on Prosopis glandulosa, May I3, I892. (Townsend).

Acmeodera sparsa Horn. Organ Mts., back of S. Augustine, on Chrysopsis villosa. Sept. I. (Wooton); Rio Ruidoso, about $6500 \mathrm{ft}$., on flowers of Achillea millefolium, July 30 . (Townsend).

A. disjuncta Fall. La Cueva, Organ Mts. (Townsend). I collected one at 

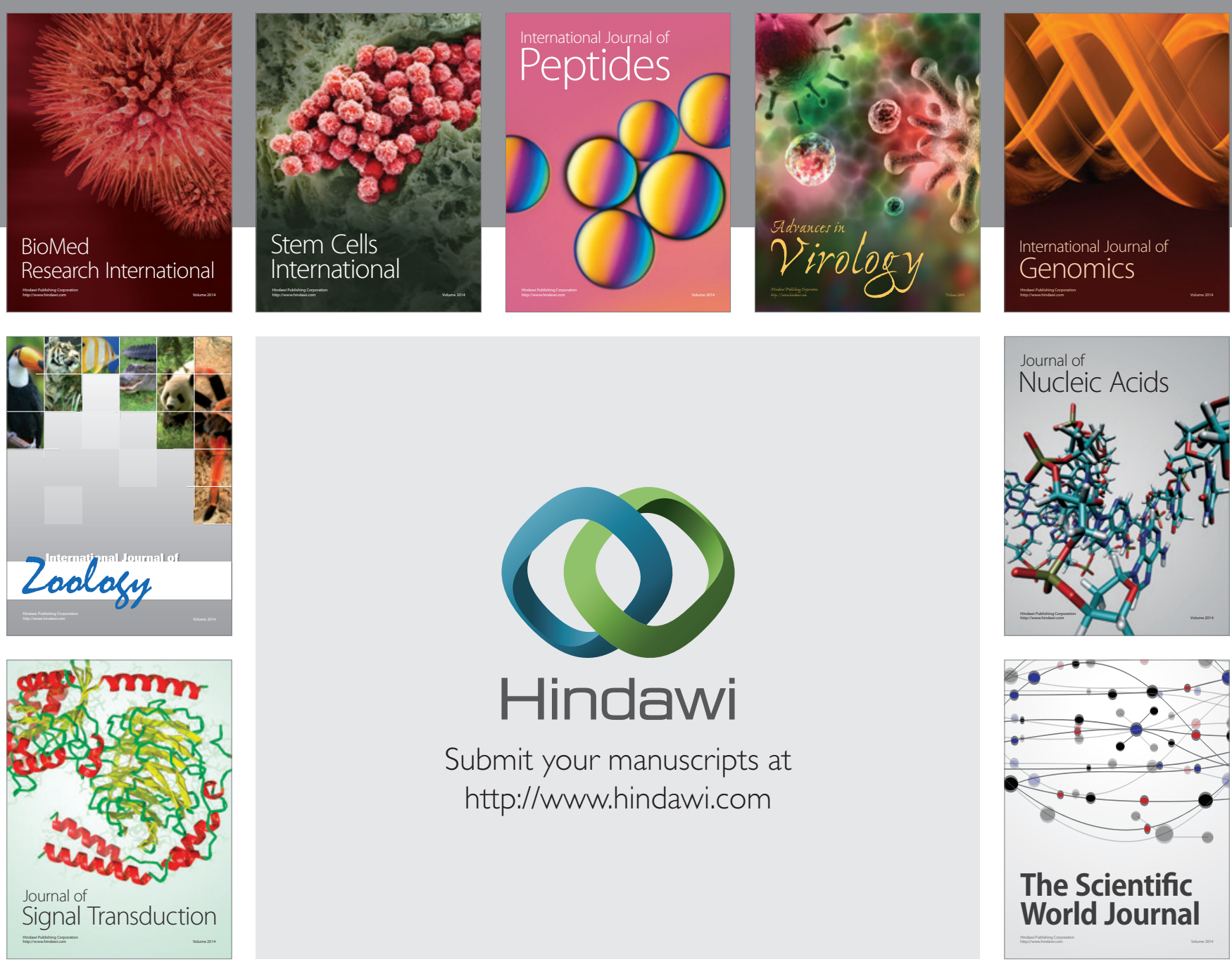

Submit your manuscripts at

http://www.hindawi.com
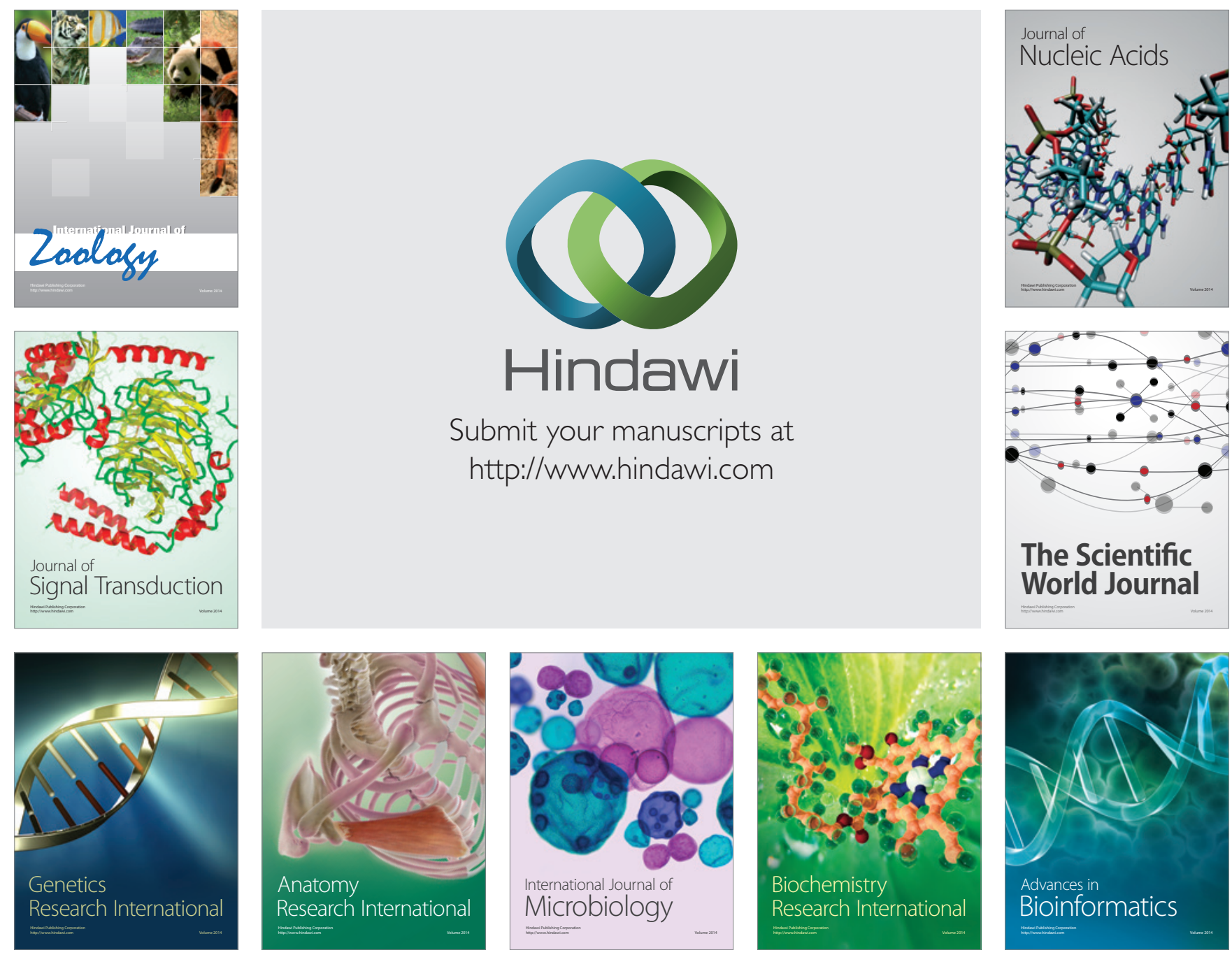

The Scientific World Journal
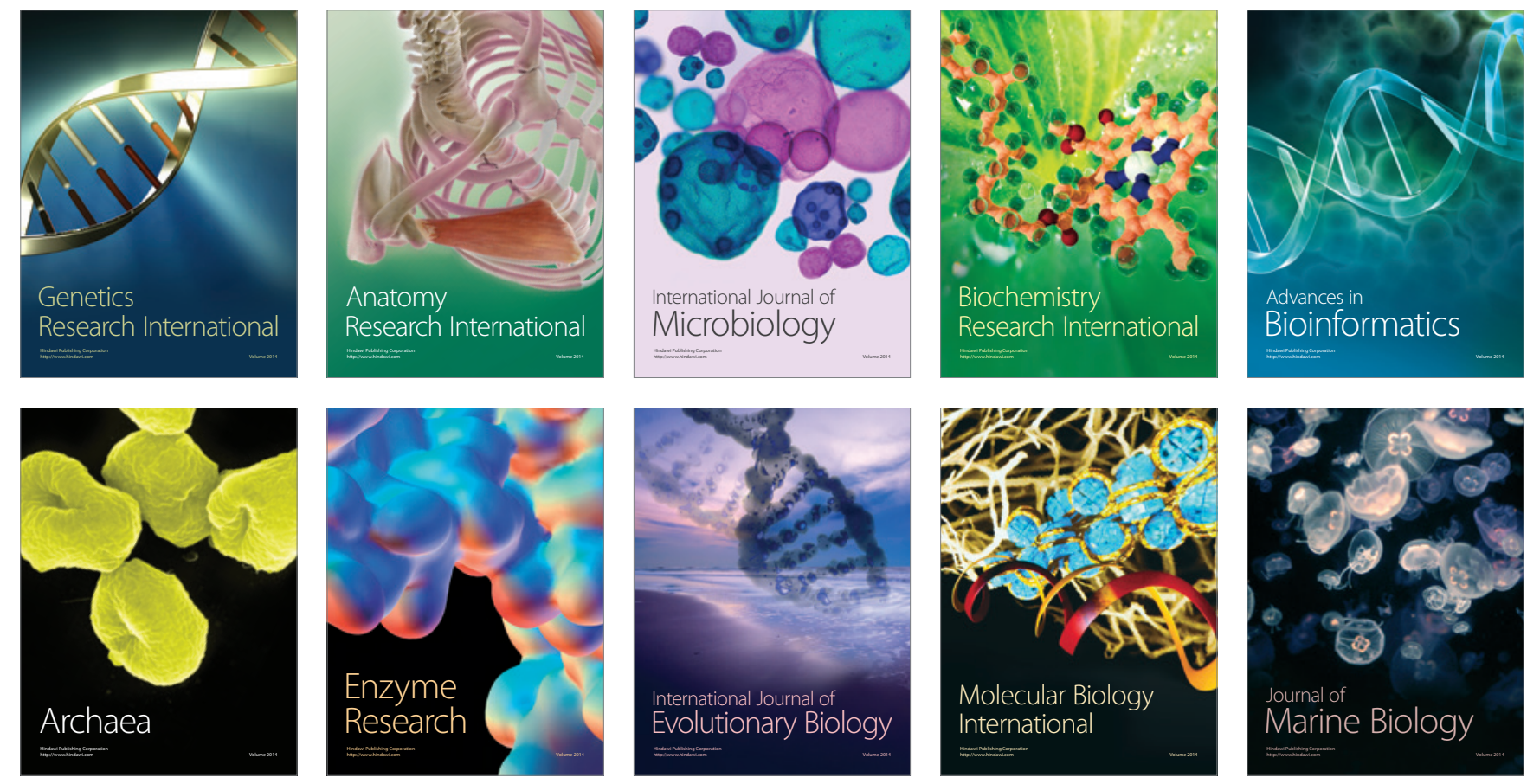